Özge Maviş Sevim

Department of Educational Sciences, Tokat Gaziosmanpaşa University,

Tokat, Turkey

Original scientific paper

Fevzi Dursun²

UDC: 371.21

Department of Educational Sciences, Tokat Gaziosmanpaşa University,

Tokat, Turkey

\title{
WHY CAN'T WE DO IT AS TEACHERS? ENGLISH LANGUAGE TEACHING FROM THE PERSPECTIVES OF SECONDARY SCHOOL TEACHERS
}

\begin{abstract}
The purpose of this study is to discover the issues in teaching English from the perspective of teachers. The qualitative method was employed in the study by using semi-structured interview forms to 19 teachers from a central Black Sea region province of Turkey. The teachers highlighted the impact of learningteaching process, teacher training, teacher-stakeholder relationship and students during the study. According to the teachers, students' prejudices against foreign language learning, interest in the subject, awareness of the importance of language learning, speaking skills, participation in the lesson and the environment they take the courses affect the language learning process. Nevertheless, the reasons for the problems are a lot more complex than this. The students are also need to be supported by the education system, by the parents and by teachers in this process. For instance, the results shows that there is a need for activities that will make students more active, and more suitable environments and materials (i.e.books) are needed for English language teaching. Also, the teachers need to the support of parents, administrators, and the other teachers to become more efficient. This research once again reveals the importance of interrelation of all factors and stakeholders as well as students' willingness and thoughts in teaching English.
\end{abstract}

Keywords: English language teaching (ELT), English teacher, secondary school, semi-structured interview.

\section{Introduction}

Speaking a foreign language has always been one of the features that grant a privilege to a person. However, today, speaking a foreign language has become a necessity as well as a contribution to the individual. Thanks to technological advances, it has become possible for individuals using different languages to come together in real or virtual environments and share their views. Foreign language knowledge provides better understanding of different cultures, creates new business opportunities, increases academic success and helps individuals to communicate with the people all over the world (Iscan, 2011). The need for a common language increases to take advantage of these situations and opportunities. Particular

\footnotetext{
1 ozge.mavis@gop.edu.tr

2 fevzi.dursun@gop.edu.tr
} 
importance has been given to the teaching and learning of English as a foreign language since it has become a common language of communication (lingua franca) in the world (Yaman, 2018). Thanks to the use of English as a common language, individuals with a different mother tongue can easily communicate (Seidlhofer, 2005). For this reason, English has been accepted as a global or world language (Harmer, 2007). Studies conducted on national and international scales on teaching English as a foreign language show that great importance is given to English language teaching (Cook, 2016; Hall, 2011; Murray \& Christison, 2011; Seidlhofer, 2005; Short, 2017; Tosuncuoglu, 2018). All of these studies, carried out on English language teaching and learning, aimed to make language learning easier and more permanent.

It is well known that various factors play a role in language teaching as in every teaching activity. The stakeholders of educational activities, including teachers, administrators, parents, and particularly students, are both affected by the instructional activities and influence them. For this reason, studies carried out on these stakeholders try to discover how language teaching is achieved and to determine the factors needed to improve teaching. In particular, teachers have played a major role in educational activities from past to present. If the teacher is not competent enough, it is difficult for other variables in the educational environment to be successful; whereas a competent teacher can reverse many negative conditions and bring success (Mavis, Cayci \& Arslan, 2014). Murray and Christison (2011) indicated that teachers played a key role in the performance of language teaching and the teachers may need something to facilitate their educational activities. They identified these things as the context in which teachers were involved, their perspective on English and how teachers learn English, and the role of teachers in language teaching. Norton (2016, p. 475) stated that for language teaching to be more effective and permanent, there should be a more productive link between theory and practice and between the ideas about language teaching and the experiences of students and teachers. The ideas expressed by teachers based on their experiences in the language teaching process are of great importance in making language teaching more effective and efficient.

The review of the relevant literature has shown that there are many studies carried out on various topics related to English language teaching. In one of these studies, Butler (2004) tried to discover the English language proficiency of elementary school level English teachers from Korea, Taiwan and Japan and found out that English teachers feel themselves more proficient in receptive skills (listening and reading) than in productive skills (speaking and writing). In her study, Chacon (2005) attempted to explore self-efficacy beliefs of English teachers from Venezuela. She discovered that teachers' efficacy level for instructional studies was higher than efficacy levels related to management and engagement. Also, studies on English teachers' qualifications, training, teaching experience and professional development are encountered in the literature. For example, Yesil Cinar and Cakir (2018) conducted a study to reveal English teachers opinions and practices about their professional development. Emery (2012) designed a large-scale research to explore English teachers' qualifications, training, teaching experience and career development. She collected data from nine countries (Bangladesh, Cambodia, Cameroon, Cuba, Egypt, India, Sri Lanka, Thailand and the United Arab Emirates) and made some suggestions and implications to initial teacher training, professional development and promotion opportunities of teachers. Other than these concepts, English teachers' attitudes and motivations on language teaching was searched in many studies (Chang, 2011; Garcia-Nevarez, Stafford \& Arias, 2005; Wlosowicz, 2017) and these studies generally indicated that teachers' motivations and attitudes towards language teaching and also to the students play a significant role in language teaching. Furthermore, problems and opportunities that teachers face while teaching English and training needs of teachers were 
tried to be discovered to make English teaching more efficient and effective. Noom-Ura (2013) conducted her research with high school teachers in Thailand to find out problems and professional development opportunities of English teachers. Problems involving teachers, students, curricula and textbooks, assessment and other factors were mentioned in her study. Yaman (2018) aimed to explore the challenges experienced in Turkey about language teaching by a review of literature, and stated that English teachers were of great importance in solving the problems of language teaching. Likewise, Mede and Isik, (2016)and Nicolaidis and Mattheoudakis (2008) tried to determine the in-service training needs of teachers by emphasizing the importance of teachers in English language education. As it is seen, all the studies tried to improve the situations in language learning and showed us to the importance and place of teachers' role in English language teaching. Based on this importance given in many research, we planned to reveal the problems teachers experience in teaching English by their own perspectives, get clearer picture of problems in teaching English in secondary school level and to offer solutions for these issues. As in many countries, English language teaching and learning is given great importance in Turkey. For example, students take 1296 hours of English classes; receiving 720 hours in primary and secondary school, and 576 hours in high school education. Also, English teaching started from the second grade of primary school beginning by the 2013-2014 academic year (Mavis and Bedir, 2014). In addition, training programs are constantly updated to ensure that English language education is carried out in a healthy manner (Yucel, Dimici, Yildiz ve Bumen, 2017). According to Yaman (2018), in Turkish context, we had some challenges like deficiencies in teacher qualifications, the existing prejudices related to the English language teaching and learning process, problems in domestic English course books, the insufficient teaching and assessment tools. Nevertheless, we also have some facilitating factors like a well-prepared English curricula, technological developments, accessible resources and international projects offering exchange programs. Although great efforts have been made to make language teaching better, it is observed that students still have difficulties in language acquisition and use. In this research we desired to evaluate these situations from the eyes of teachers and discuss what can be done to make them better. It is believed that the discovery of issues in teaching English from English teachers' perspective will contribute to the studies in language teaching and learning and English as a second language studies literature and to the English teaching and learning process by revealing the current situation and problems, discussing these situations and issues and proposing solutions to make English teaching better. For this reason, the purpose of this study is determined as to discover the issues in teaching English from the perspective of teachers by using interview method. For this purpose, the answers were searched for the following questions.

What are the views of secondary school level English teachers on:

1) English learning and teaching process?

2) English teachers' training process?

3) The relationship between English teachers and other stakeholders?

4) The students who are taught English?

\section{Method}

\subsection{Research Design}

In the study, explanatory case study pattern, which is one of the qualitative research method, was used. In qualitative research methods, researchers generally collect open-ended and emerging data and it is usually take place in a natural setting and it has fundamentally interpretive nature (Campbell, 2014). This method is "an approach that allows you to examine 
people's experiences in detail by using a specific set of research methods such as in-depth interviews, focus group discussions, observation, content analysis, visual methods and life histories and biographies" (Hennink, Hutter and Bailey, 2020, s. 10). The case study pattern is defined by McBurney and White (2010, p. 221) as the "discovery study of an existing situation". Jackson (2009, p. 85) likewise described the case study as "a study aiming at an in-depth study of one or more individuals in the hope of revealing the things that are right for everyone". The determined situation may be a specific person or group, or it may be an organization, activity, process or event (Christensen, Johnson \&Turner, 2015; McBurney \& White, 2010). Explanatory case study is used to "give information about a situation, make unfamiliar situations familiar and explain the connections with life experiences" (Kaleli-Yilmaz, 2014, p. 269). One of the most important features of this pattern is the focus on the perceptions of the people or groups participating (Ekiz, 2013).

\subsection{Study Group}

In the study, the sample was determined by using the typical case sampling method, which is one of the purposeful sampling methods. 19 secondary school English teachers (14 females/5 males) working in secondary schools from a central Black Sea region province of Turkey participated. Typical case sampling means "selection of individuals who are likely to behave like others" (Bamberger, Rugh \& Mabry, 2011, p. 361) and illustrates typical, normal, or average situations. The purpose of typical case sampling is to learn what is known about the case in average rather than general explanations about the experiences of all participants (Patton, 1990). We aimed to study and have an idea about the existing situations and to provide more in-depth information in a particular problem and this sampling method can give in-depth information about the issues of English language teaching. Also, the number of participants is limited 19 and getting in-depth information is facilitated by working with a small group of participants. In order to ensure that the teachers participating in the study have resembling characteristics with other teachers who were not participate in research, it was paid attention that teachers were selected from both the first years of their profession and the experienced ones. The working experience of the interviewees ranged from 4 to 15 years $(N=19, S D=7,77)$. The teachers selected for interviews in the study were limited to individuals who taught English at the secondary school level $6^{\text {th }}, 7^{\text {th }}$ and $8^{\text {th }}$ graders from different public and private schools. By putting all these selection criteria, it is tried to be ensure that participant teachers have resembling qualifications to those who did not participate in the study.

\subsection{Data Collection Tool and Data Analysis}

In this research, we use interview method to collect the data. Interview method means to "conversation for gathering information" and in this process there is an interviewer who asks the questions and an interviewee who answers these questions (Easwaramoothy and Zarinpoush, 2006, p.1). Most of the time this method is used in qualitative research to collect in-depth information about people's opinions, thoughts, experiences and feelings. There are three types of interviews as structured, semi-structure and unstructured. We used semi-structured type because it is useful for "collecting in-depth information in a systematic manner from a number of respondents or interviewees (e.g., teachers, community leaders)" (Easwaramoothy and Zarinpoush, 2006, p. 1).Data were collected through a semi-structured interview form developed by the researchers (see in appendix 1). The literature was examined while developing the interview form. When the relevant literature was investigated, it was thought that the problems experienced by teachers 
might be related to the learning-teaching process, education stakeholders, education level and the quality of the education the teachers received and students. As a matter of fact, there are studies in this context in the literature (Behroozi \& Amoozegar, 2014; Noom-ura, 2013; Hu, 2005). A semi-structured interview form was created investigating these studies, research questions of these studies and the questionnaires they used. To ensure the validity of the questionnaire, the form was submitted to the opinions of 3 experts. They are the expert in the field of Curriculum and Instruction department. One of the experts has Master of Science (MA) degree while two of them have doctorate (PhD) degree. There were 9 main and 12 probing questions in the interview form, which was finalized according to expert opinions. Probing questions were used to get more information from the teachers when necessary.

The interview data were analysed using the content analysis method. Content analysis means to "a research technique for making replicable and valid inferences from data to their context" (Krippendorff, 1989, p. 403). As White and Marsh (2006) indicated, in qualitative content analysis, a humanistic tradition and inductive method is conducted. In inductive content analysis method, coding scheme usually developed to identify significant concepts and patterns, and in a subjective manner, it is tried to document perceptions and formulations. For the purposes of the current study, inductive content analysis is considered appropriate to further understanding of issues experienced by English language teachers in their teaching process. In the data obtained through interviews, the process goes on with steps such as coding the data, finding themes, arranging the codes and the themes, and defining and interpreting the findings. These steps are deemed useful in terms of facilitating the usage of categorization. Also, interpretation and the discussion of the data obtained become easier (Yildirim \& Simsek, 2008).

\section{Findings}

The findings were presented by taking the questions into consideration for which responses were searched under the general aim of the study.

\subsection{Views on Learning-Teaching Process}

In line with the opinions of the teachers who participated in the study, the theme "the learning-teaching process" included codes related to this theme and these views are summarized in figure 1.

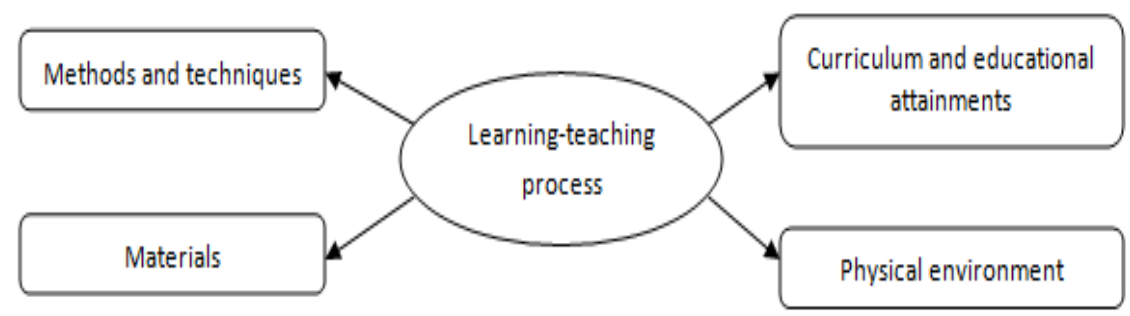

Figure 1. Codes for "Learning-teaching process" 


\subsubsection{Methods and Techniques}

In general, teachers indicated that they mainly used methods and techniques that would make students active and improve their communication skills. The methods used by the teachers included active learning and cooperative learning methods. Particularly, considering the psycho-motor needs of young learners, activities that allow in-classroom movement were more frequently employed. As the age group got older, vocabulary teaching, reading comprehension, and writing skills were stated to be involved more frequently. Teachers who mentioned the importance of learning language with fun said they employed techniques such as games, singing, videos, dialogues, drama, role playing, group and pair-work, and questionanswer techniques in classroom activities. The majority of teachers were found to give great importance to speaking and listening activities. However, two of the teachers stated that although developing communicative skills were considered to be the general objective of teaching, teachers gave more place to grammar teaching in their classes, and this was because the high school transition exam supposed to betaken at the end of the $8^{\text {th }}$ grade heavily involved grammar-based questions. Sample expression regarding teachers' opinions is as follows:

“(...) I aim to develop four basic language skills of students in the lessons. I apply active learning and cooperative learning techniques that allow a studentcentered classroom environment. In particular, I carry out my classes using activities such as making dialogues, question and answer, group work, and pairwork." (T19)

\subsubsection{Materials}

Teachers mentioned that they made use of materials that could activate students in accordance with the methods and techniques they employed. Visual materials included vocabulary flashcards, photos, colourful and illustrated board materials, while audio materials consisted of songs, videos, and cartoons. Teachers also mentioned that they utilized dictionaries, textbooks, and test books as written materials in their lessons. Also, the materials on the Education Information Network (EBA) portal were used to attract the attention of some of the students and can increase their motivation. On the other hand, teachers said that they used textbooks, but that the books were inadequate for developing communicative skills. Sample expression regarding the materials used is as follows:

"I use material from the EBA portal. I also use my own materials. I make use of vocabulary flashcards and videos to raise interest.... Although we talk about the inadequacy of English books at the meetings held every year, we cannot design books to develop communicative methodology. I would like to have such a book developed." (T18)

\subsubsection{Curriculum and Educational Goals}

The teachers indicated that the level of educational goals varied according to the willingness of the student and the level of the class. Besides, some teachers said that the English language teaching curriculum was more intensive in comparison to the course hours and they could not achieve the goals due to the intensity of the program. An example of opinions about this topic is as follows. 
"Time [allocated for the curriculum] is not enough. There's such a program that asks you to teach a lot of things together. But we can't teach everything within the scope of 4 skills. I mean I can't achieve those goals. Listening, speaking, reading, and writing; it is very difficult to handle the four together."(T1)

\subsubsection{Physical Environment}

Some of the teachers find the environment or the materials used inadequate. These teachers stated that the availability of smart boards in each classroom was a positive step with the latest regulations, but they added that other physical conditions caused problems in conducting game and drama activities and that they had problems in implementing some activities due to the crowded class size. Sample statement regarding these comments is as follows.

"Smart boards are useful, but physical conditions and the class size bring about disadvantages for language teaching." (T17)

\subsection{Views on Teacher Training}

In line with the opinions of the teachers who participated in the study, the theme "views on teacher training" included codes related to these theme and these views are summarized in figure 2 .

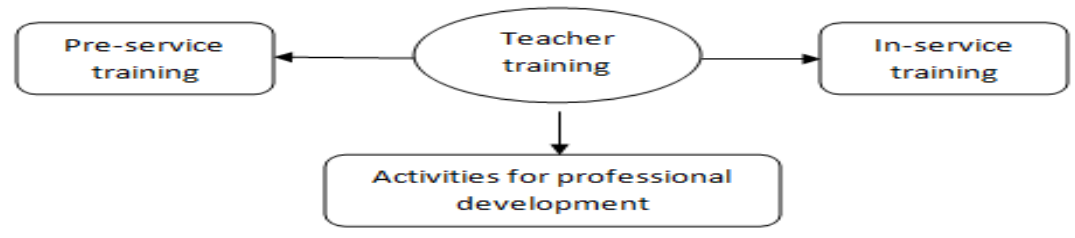

Figure 2. Codes for "Teacher training”

\subsubsection{Pre-service Training}

The most emphasized issue in the comments made by the teachers about pre-service training was the discovery of the differences between the education they received and actual teaching. One of the teachers pointed out the significance of applied teaching courses by mentioning their contribution to the recognition of the teaching profession. One of the example of teachers' opinions is as follows.

"Of course, the education we received in the faculty of education made some contributions, but we forgot most of it. I mean we had a lot of possibilities there. We did what we wanted and the way we wanted. It was quite simple to teach there as there were no real students. When I met real students, it turned out to be not that simple." (T5)

\subsubsection{In-service Training}

Six of the teachers talked about in-service training events. While three of the teachers found the in-service training events useful, the other three of them stated that they could not benefit from these training activities. Teachers who thought these training events were beneficial said 
it was because the trainers were well-equipped, and qualified instructors and the training provided interactive and active participation. On the other hand, those who thought the training events were not useful said it was because the trainers were not selected well, the lessons were monotonous, the setting and the hour of the training schedule were inappropriate, the trainers talked only about regulations, and the training lacked practice. Sample statement regarding these views is as follows.

"Of all the in-service training events I have attended so far, I have benefited most from the ones which were organized in the last years with the participation of foreign trainers (native speakers). This was because we had to speak English all the time. I don't think other training events were productive because they were given through PowerPoint presentations in a monotonous way." (T18)

\subsubsection{Activities for Professional Development}

The teachers who participated in the study mentioned that they generally read foreign books and articles and watched films for their professional development. Activities of the teachers for professional development also included graduate studies, participation in international projects, following websites related to the English language learning and teaching, finding out about new teaching methods, consulting colleagues, and participation in seminars and courses. One of these statements are as follows:

"I often search the Internet for my professional development. I especially investigate education-related websites to find out about new teaching methods. I usually try to get help from my friends who work in private schools.... We should be open to innovations. I always search for new things. To improve myself in my field, I constantly read English books so that I can keep my English level high. I often read resources and watch movies in English." (T9)

\subsection{Views on Teacher-Stakeholder Relationship}

In line with the opinions of the teachers who participated in the study, the theme "views on teacher-stakeholder relationship" included codes related to this theme and these views are summarized in figure 3 .

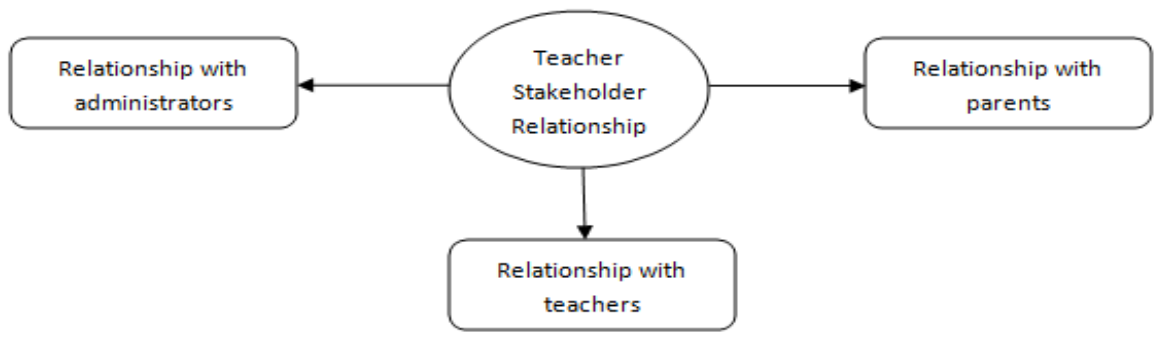

Figure 3. Codes for "Teacher-stakeholder relationship" 


\subsubsection{Relationships with Administrators}

In general, teachers pointed out that they received the necessary support from administrators. However, some teachers said they had some expectations from administrators. Among these expectations, the most emphasized issue was giving importance to English lessons and putting the pressure on teachers for the reason that the students are not successful in English learning. Also, teachers stated that administrators should improve themselves, they should learn a foreign language, and they should not consider language teaching only exam-oriented. One of the teachers' statement is as follows.

"(...) I expect that teachers should not be pressed too much due to students' failure in learning English." (T14)

\subsubsection{Relationships with Parents}

Teachers often indicated that parents paid attention to English language teaching and they believed their children should learn a foreign language. However, they also said that for the reason that many parents did not know English, they had difficulties in giving support to their children. While some of the teachers stated that parents gave more importance to courses such as mathematics, science, and Turkish, one teacher stated that English lesson was getting more and more important due to the coverage in the high school transition exam. One of the problems is that parents have high expectations related to learning English. Some of the statements regarding these views are as follows.

"All parents want their children to learn a foreign language; however, they always say, 'we cannot give any support at home'. The only opportunity to use their English is practicing with me and with their friends. Very few parents can help at home, but students who get help from their parents are immediately evident. I mean, it is immediately clear whether the student's parents can speak English." (T2)

"Unfortunately, we sometimes have problems with parents. They expect students to immediately show what they have learned. This is not possible instantly. They have high expectations about the learning process." (T12)

\subsubsection{Relationships with Teachers}

The teachers who indicated that as the teachers studied in the same field, namely English Language Teaching, they supported each other in general. They also expressed that they collaborated with these teachers, they shared their materials and activities. Nevertheless, in addition to teachers who pointed out that they had no problems with the teachers who are in different fields, some English teachers reported that they had problems with teachers who are in different fields because some of these teachers considered their lessons more important and they did not want to share their materials. Furthermore, some teachers indicated that in some schools, there is no appointment in English language teaching field. For this reason, the teachers who are in different fields were commissioned to teach English, which caused another problem. One of the statement is as follows.

"... Some teachers care about their lessons more than yours. You know, maybe, we do the same thing to teachers of other fields like mathematics or science. For 
example, some classes have a projector. We want to use the device. We want to change the classroom. The teacher of the classroom does not accept it... things like this. It usually emerges out of deficiencies." (T8)

\subsection{Views on Students}

In line with the opinions of the teachers who participated in the study, the theme "students" included codes related to these theme and these views are summarized in figure 4 .

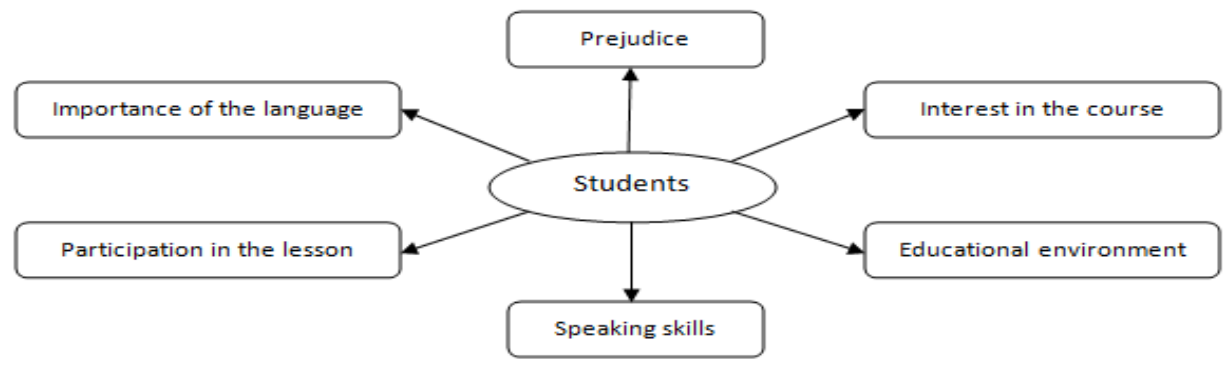

Figure 4. Codes for "Students"

\subsubsection{Prejudice}

The teachers stated that one of the problems they encountered is that students believed they wouldn't be successful in this course and they had prejudices against the necessity of learning English. Teachers first try to convince their students that they will be able to do the course and this course is necessary. Examples of these views are as follows.

"Yes, there are students who have prejudices. There is one student saying, 'I can't do that; I am unable to learn English." (T2)

"Usually we encounter such cases. Students have a prejudice against language learning and they say, 'why are we learning this language?' This is the most challenging problem." (T5)

\subsubsection{Interest in the Subject}

Under this code, teachers mentioned the indifference and reluctance of students towards the lesson. The teachers thought this stemmed from the fact that students were unfamiliar with the language, they thought they were unable to handle it, there was no environment to use the language, and the percentage of the English language field in the high school transition exam was low. One of the views of the teachers under this code is as follows.

"Sometimes the students can be reluctant to participate in the lesson. In order to overcome this problem, we need to strengthen the student's belief in what s/he can do for learning a foreign language." (T4)

\subsubsection{Educational Environment}

English teachers who participated in the study stated that students did not have an environment where they would practice the language. Teachers mentioned that language teaching should not be limited to classroom activities only and students should improve their 
ability to use language in different environments. Sample statements regarding these views are as follows.

"The most important problem is that our students are not exposed to the language due to the location of the school and its environment. I mean, my students have to content with what they hear from me. It does not make much sense to them." (T8)

"The teaching and learning of the language is limited to the classroom environment. We cannot practice the language as our students do not use English outside the school. Therefore, students' speaking skills remain poor." (T16)

\subsubsection{Importance of Language}

Some of the teachers stated that one of the fundamental reasons for not achieving the objectives of language teaching was that foreign language was not seen as a need, and its importance was not fully understood by students. Sample expressions under this code can be seen below.

"The main problem we have with students is that they do not know the importance of language learning. (...) Some of our students do not see English as an important lesson." (T11)

"(...) One of the problems is that students do not consider language learning as a need." (T19)

\subsubsection{Speaking Skill}

According to the teachers, students feel ashamed, and they do not participate in the lesson actively because they think their friends will make fun of them and laugh at them. In particular, the students who are not involved in speaking activities cannot develop pronunciation, and this becomes a problem in language learning. Sample statement regarding this view is as follows.

“(...)They don't want to speak. They're ashamed; they are afraid." (T1)

\subsubsection{Participation in the Lesson}

The teachers stated that students could not retain what they learned because they did not participate in the lesson effectively and did not revise after the lesson. Below are the sample statements of teachers:

"Retention of language knowledge learned at school weakens as students do not revise." (T14)

"Because English lessons are activity-oriented, the efficiency of the lesson reduces when students do not participate in the lesson effectively." (T16)

\section{Discussion, Conclusion and Implications}

In the study, we try to discover the issues in teaching English from the perspective of teachers by conducting a qualitative research method. Throughout the study, the teachers highlighted the impact of learning-teaching process, teacher training, teacher-stakeholder relationship 
and students during the study. The teachers reported that they frequently use methods and techniques based on active learning and cooperative learning and selected the materials according to these methods. As it is known, the use of methods, techniques, and materials that will make students active and provide cooperative learning are considered to have great effects on the attitude towards the course, student motivation and achievement, thinking skills and retention of what has been learned (Dursun and Bulut, 2019; Dornyei, 2005; Nunan, 2015; Richards \& Rodgers, 2001). In the research, teachers indicated that they use active and cooperative learning methods and techniques. However, some teachers mentioned that although language classes were claimed to involve activities aiming to improve communicative skills and making students active learners, teachers actually gave more place to grammar teaching in their classes. They explained the reason of this as the high school transition exam that students are supposed to be taken at the end of the $8^{\text {th }}$ grade was highly based on grammar-related questions. In fact, language teaching is based on four basic skills (i.e. reading, writing, speaking and listening) as well as grammar knowledge, and lessons include goals for the development of them. The importance of students' knowledge of grammar rules in language learning is undeniably valuable. Nevertheless, an assessment system that focuses solely on grammar teaching may result in ignoring other skills. For this reason, including a measurement and assessment system that covers these four skills as well as grammar-based skills in the exams is of great importance in terms of student development in all aspects of language learning. As Taylor (2006) indicated, assessment makes a 'washback' effect on learning.

As it is well known, in addition to the usage of methods and techniques and assessment activities for English teaching, textbooks also play an important role in fulfilling educational goals and should be designed to foster all skills of students (Harwood, 2014). For this reason, in the research, the teachers' opinions about textbooks were also received and they explained that some textbooks were inadequate for developing communicative skills. In different research conducted in Turkey for the evaluation of the English textbooks, some resembling results were obtained. In their research, Guven and Saracaloglu (2020) indicated that $9^{\text {th }}$ grade English course books were insufficient in many aspects in terms of content, learning-teaching and evaluation process. Senerve Mulcar (2018) conducted a research to evaluate $10^{\text {th }}$ graders' English textbooks from the perspectives of teachers and they also found out that the teachers most important criticism to the books stated as inadequate supplementary materials. They indicated that they could not perform listening and speaking activities for the reason that they have limited activities and supplementary materials related to improvement of these skills. Based on the findings of our study and other studies, it is possible to say that English textbooks can become more functional by considering these issues and giving more space to activities for improving all the competencies required for learning English.

When asked about the achievement of educational goals in English teaching, the teachers indicated that the achievement differed according to the willingness of the student and the level of the classroom. According to the teachers, English teaching programs were structured with intensive course hours, and the intensity of the program made achievement of the goals more difficult. To solve this problem, the teachers recommended increasing the number of English classes and establishing preparatory classes in which intensive English teaching programs could be administered. Actually in Turkey, intensive English education was provided at high school level under the name of 'preparatory classes' through Anatolian high schools in order to provide a better language teaching from 1955 to 2005. Although these preparatory classes increased the success in English teaching, they repealed in 2005-2006 academic year (Coskun-Demirpolat, 2015). In the 2017-2018 academic year, a pilot study was conducted to 
establish preparatory classes in which intensive English education was given in $5^{\text {th }}$ grade and some studies were conducted to evaluate this pilot study. The studies showed that the teachers and administrators were satisfied with this practice and wanted it to continue (Dilekli, 2018; Kayabasi \& Kose, 2019). Based on the results in our study and other studies, it can be said that it may be beneficial to create intensive preparatory classes in a way that gives more space and time to English teaching to improvement of English language learning.

Teachers said that the availability of smart boards in each class with the latest regulations was a positive step, but that other physical conditions caused problems in playing games and performing drama activities, and they had problems in implementing some activities due to the crowded classes. According to a study made by the Turkish Ministry of National Education in Turkey, in secondary school level, class members consist of 43 students on average (MoNE, 2014). Problems regarding crowded classes and inappropriate physical conditions have also been addressed in different studies and these studies indicated that the problems were experiences with regard to conducting communicative language based activities and assessment processes (Coskun-Demirpolat, 2015; Gok-Catal, Sahinve Celik, 2018; Haznedar, 2010). As a matter of fact, Brown (2001) also mentioned that in crowded classrooms the chance of students to participate in the class activities decreased and the feedback given by the teacher to the students became limited.Nevertheless, studies conducted in recent years show that the use of physical environment and technology (smartboards, projectors, educational portals, etc.) in schools has been gradually improved and this has positive effects on the lessons (Buyukyavuz \& Inal, 2012; Dilekli, 2018; Guven \& Akar-Vural, 2017). Based on these results, it can be said that increasing the number of schools and classrooms and also the place and technology in schools throughout the country can be beneficial for improvement of English language teaching.

When the teachers participating in the study were asked about pre-service and in-service training, the teachers explained that there were some differences in the application of the theoretical knowledge they received during pre-service training, and therefore they had some problems. According to the teachers who participated in our study, teaching practice courses taken in pre-service education were useful in terms of learning about the teaching profession and made great contributions. The importance of teaching practice courses in terms of understanding the profession, and gaining experience and the necessity of giving more place to these courses in pre-service education have also been addressed in various studies (Aslan \& Saglam, 2018;OzCelik, 2012).

Some of the teachers indicated that they found in-service training activities beneficial, while others thought they could not benefit from them. Teachers who thought in-service training activities were beneficial stated that this was because the trainers/instructors in the activities were qualified and provision of interactive activities allowing active participation. On the other hand, those who thought the training events were not useful said it was because the trainers were not selected well, the lessons were monotonous, the setting and the hour of the training schedule were inappropriate, the trainers talked only about regulations, and the training lacked practice. In-service training activities for teachers are of great importance because these activities play an important role in improving and updating teachers' field knowledge and pedagogical knowledge (Martin, 2002; Saiti and Saitis, 2006). For this reason, in-service training activities are improved through the findings of various studies conducted not only in Turkey but also abroad (Aribas, Kartal \& Caglar, 2012; Gandara \& Lucrecia, 2016; Karaata, 2010; Nicolaidis \& Mattheoudakis, 2008). In one of these studies, Yigit and Altun (2011) developed an in-service training program that was structured based on the needs of teachers and provided 
active participation. Teachers indicated that they became more efficient thanks to in-service training activities which provided application opportunities. Based on these findings, it is possible to say that in-service training activities that are carried out in a suitable place, time and environment where teachers' needs are met and which allows active participation will benefit teachers' professional development.

The field knowledge which means the knowledge of concepts, principles, and generalizations that teachers teach in their lessons and the pedagogical knowledge which comprises knowledge of a teacher about how to teach their courses are of significance in terms of conduction teaching and learning activities (Dos, 2016). In this study, the teachers stated that they utilized books and films in English to improve their knowledge of the field. Teachers' efforts for their professional development also included doing master's degree, taking part in international projects, following web sites related to English language learning and teaching, studying new teaching methods, consulting colleagues, and attending seminars and courses. It is seen that teachers tried to participate in many activities in order to ensure their professional development. In addition to the activities teachers do themselves to improve their proficiency, increasing the number of professional development workshops, meetings and activities that increase cooperation of teachers could also be organized to help teachers improve themselves. As Noom-ura (2013, p. 146) stated "the training courses that help improve teachers' English proficiency are highly valued."

The teachers indicated that they generally received support from school management and administrators but some teachers stated that they expected administrators to give more importance to English lessons. Besides, teachers said that administrators should improve themselves, they should learn a foreign language, and that they should not see language teaching only as exam-oriented. In addition, it was also expected that administrators should be aware that language learning cannot be taught in a short time and they should not force teachers to teach everything in a short time. Another factor that causes pressure on teachers apart from administrators is parents' high expectations from teachers regarding language teaching. Obtaining similar findings, Cakir (2017) concluded that the pressure coming from parents and administrators had to be reduced for the solution to this problem by raising awareness of the parents and administrators that language learning cannot be achieved suddenly and students need time to acquire the language skills.

In the study, according to teachers, most of the parents give importance to English courses. Nevertheless, many of them do not know English and therefore cannot help their children. Teachers expect that parents should have enough language knowledge to help their children. It is a well-known fact that parents are important in the success of the child's school education (Gencer \& Cetin, 2016; Argon \& Kiyici, 2012). Based on these findings, it is possible to say that the parents' self-improvement in language acquisition and their ability to help the students can positively affect students' language acquisition. In fact, in this context, other than parents' support, it is important to ensure that students acquire independent study habits. When students gain the habits of independent study, the demand for help expected from parents will gradually decrease. Other than this, as the teachers stated in this study, students have limited time in the classroom to use the language, and for this reason, the need for autonomous learners who can effectively continue their learning outside of school increased. To ensure autonomy in language learning, providing students to take their own learning responsibilities (Kormos \& Csizer, 2014; Kurt \& Acat, 2016) and to have intrinsic motivation as well as extrinsic one (Fazey \& Fazey, 2001; Ustunoglu, 2009) can be beneficial. Also, directing 
them to materials and resources that they can work independently can be useful to increase their success in learning English.

English teachers generally indicated that they often support each other, work in collaboration with teachers who are in the same field, and share materials and activities but a few teachers stated that they had problems with some teachers who are in a different field (like mathematics teachers, social science teachers etc.). In Turkey, all teachers have to use the same materials because the same class is used for each lesson. Some of the teachers participating in the research stated that some teachers from different fields did not want to share the class materials because they thought that their courses were more important and they needed these materials more than English teachers. For solution to this problem, it may be suggested to increase the number of classrooms and create subject-based classroom system which means that each lesson has its own class. As a matter of fact, it has been discovered in different studies that the subject-based classroom system has a positive effect on student achievement and attitudes (Ozyurek, Pinarkayave Tas, 2016). In addition, it has been found out that the teachers from different fields are satisfied with this practice in the schools where these system is applied (Kaya, 2012; Kiryakve Altun, 2019).

In Turkey, English teacher appointments cannot meet the needs of all country (Kiraz \& Kurul, 2018) and for this reason, some schools do not have English teachers and teachers from different fields have to conduct English lessons. Since these teachers do not have much knowledge about English language teaching methods and techniques, there may be difficulties in conducting education in a healthy way and in this research, teachers also mentioned that situation. Similarly, Sevik (2009) reported that in some elementary schools, teachers from other fields who did not have enough knowledge about lessons in English language teaching fields were commissioned to teach English. Sevik (2009), who stated that not all teachers with English certificates can conduct English lessons effectively, reported that the appointment of teachers other than English teachers to teach English would affect language achievement to a great extent. Therefore, English lessons should be carried out by real 'English teachers' who graduated from English Language Teaching Departments of Education Faculties. Appointment of graduates from English Language Teaching departments and conducting English lessons by these teachers can increase the success in English teaching.

According to the teachers, one of the main reasons why students could not achieve the goals in language teaching was that they had some prejudices against foreign language learning. Some students did not see foreign language as a need, and could not understand the importance of language learning. Also, according to the teachers participating in the study, some students were indifferent and reluctant to learn English because they found learning a foreign language difficult, they did not have a suitable environment to use the language, and the contribution of the language field to the high school transition exam was low. In many studies, interest and motivation in language learning are mentioned as important factors (Csizer \& Dornyei, 2005; Mehdiyev, Usta \& Ugurlu, 2016; Oxford \& Shearin, 1994; Paker, 2012). Therefore, first of all, convincing the students about the importance and necessity of the lesson and maintaining their interests and motivations will facilitate English Language teaching and learning. Also, some students were found to have prejudices against the lesson because they thought they would not be successful in this course. This reveals that language learning anxiety has an impact on language learning. In general terms, language learning anxiety is defined as "the feeling of tension and apprehension specifically associated with second language contexts, including speaking, listening, and learning” (Macintyre \& Gardner, 
1994, p. 284), and it causes learners to become nervous, stressful and worried while learning a foreign language (Macintyre, 1999). In the literature, there are many studies which supported the idea that the anxiety of learning a foreign language has a great effect on learning a new language (Horwitz, 2001; Horwitz, Horwitz\& Cope, 1986; Naser Oteir \& Nijr Al-Otaibi, 2019). Anxiety affects especially speaking skills to a great extent (Melchor-Couto, 2016; Woodrow, 2006). The teachers in this study stated that students did not want to participate in the lesson actively because they were afraid that other students would make fun of them. In particular, pronunciations of students who are not involved in speaking activities do not improve and this situation becomes a problem in language learning. The organization of learning environments that reduce the anxiety of students and provide them with comfort will help conduct language teaching more successfully. The non-threatening, supportive environments in which structured cooperative learning activities is conducted can be beneficial for reducing the anxiety (Nagahashi, 2007). Also, the environments where the students can play games, do pair works, watch films and listen to music can be arranged to foster the needs of learners (Young, 1991). Furthermore, teacher-student communication and reinforcement of trust between them will play an important role in student participation and reducing anxiety (Sevik, 2009). The teachers indicated that students had difficulty retaining what they have already learned because of the lack of active participation and revision. The non-threatening, supportive environments in which structured cooperative learning activities is conducted can be beneficial for reducing the anxiety (Nagahashi, 2007). Also, the environments where the students can play games, do pair works, watch films and listen to music can be arranged to foster the needs of learners (Young, 1991). Furthermore, teacher-student communication and reinforcement of trust between them will play an important role in student participation and reducing anxiety (Sevik, 2009). The teachers indicated that students had difficulty retaining what they have already learned because of the lack of active participation and revision. This problem can be overcome by increasing student-student and teacher-student interaction, creating environments where students can express themselves comfortably and enabling students to gain independent study habits. The teachers also added that language teaching should not be limited to in-class activities and students should develop skills to use the language in different environments.

Consequently, in this study, English teachers' opinions related to issues about English language teaching tried to be find out and their views were evaluated and discussed under the headings of learning-teaching process, teacher training, teacher-stakeholder relationship and students. Although this study is a small scale study limited to perspectives of secondary school teachers from Turkey, it is thought that it will contribute to some extent in shedding light on the problems related to English teaching and finding solutions to these issues. In the study, problems were tried to be revealed only with the perspectives of English teachers. In future studies, studies can be carried out to reveal the problems related to English teaching from the perspectives of students, administration, parents, policy makers, and faculty members of English Language Teaching Departments.

\section{References}

Argon, T. \& Kiyici, C. (212). Teacher views in primary schools about parental participation in education, Dicle Universitesi Ziya Gokalp Egitim Fakultesi Dergisi, 19, 80-95.

Aribas, S., Kartal, S. \& Caglar, I. (2012). The opinions of English teachers about in-service training activities. Milli Egitim, 195, 100-117. 
Aslan, M. \& Saglam, M. (2018).Evaluation of teaching practice course according to opinions of student teachers. Hacettepe University Journal of Education, 33(1), 144-162.

Bamberger, M., Rugh, J. \& Mabry, L. (2006). Real world evaluation: Working under budget, time, data, and political constraints. CA: Sage Publications.

Brown, H. D. (2001). Teaching by principles: An interactive approach to language pedagogy, $\left(2^{\text {nd }}\right.$ Edition). New York: Longman Inc.

Butler, Y. G. (2004). What level of English proficiency do elementary school teachers need to attain to teach EFL? Case studies from Korea, Taiwan, and Japan. TESOL Quarterly, 38(2), 245-278.

Buyukyavuz, O. \& Inal, S. (2012). A transition from course book-based language instruction towards technology-enhanced classrooms: Opinions of teachers and students regarding interactive whiteboard technology in an EFL context. Journal of Erciyes University Institute of Social Sciences, 33(2), 193-210.

Cakir, I. (2017). The wash back effects of secondary education placement examination on teachers, school administrators and parents with specific reference to teaching English as a foreign language. Turkish Journal of Teacher Education, 6(2),62-73.

Campbell, S. (2014). What is qualitative research?. Clinical Laboratory Science, 27(1), 3.

Chacon, C. T. (2005). Teachers' perceived efficacy among English as a foreign language teachers in middle schools in Venezuela. Teaching and Teacher Education, 21(3), 257-272.

Chang, M. (2011). EFL teachers' attitudes toward communicative language teaching in Taiwanese college. Asian EFL Journal, 53(1), 17-34.

Chen, H. C. (2016). In-Service teachers' intelligibility and pronunciation adjustment strategies in English language classrooms. English Language Teaching, 9(4), 30-53.

Christensen, L. B., Johnson, R. B. \& Turner, L. A. (2015). Research methods, design and analysis. (trans. AhmetAypay) Ankara: AniYayincilik.

Cook, V. (2016). Second language learning and language teaching. (5 $5^{\text {th }}$ Edition). New York: Routledge.

Coskun Demirpolat, B. (2015). Turkiye'n inyabancidi logretimiy leimtihani: Sorunlar ve Cozumonerileri. [The challenge for Turkey's foreign language teaching: Problems and solutions] istanbul: SETA.

Creswell, J. W. (2013). Qualitative inquiry and research design: Choosing among five approaches ( $3^{\text {th }}$ Edition). USA: SAGE Publications.

Csizer, K. \& Dornyei, Z. (2005). Language learners' motivational profiles and their motivated learning behaviour. Language Learning, 55(4), 613-659.

Dilekli, Y. (2018). Evaluation of Pilot scheme of secondary schools English preparatory class curriculum according to teachers' views. International Journal of Society Researches, $8(15), 1399-1425$.

Dornyei, Z. (2005). The psychology of the language learner: individual differences in second language acquisition. New Jersey: Lawrence Erlbaum Associates.

Dos, B. (2016).Determining the deficiencies of the teachers in terms of professional knowledge and skills: A qualitative study, Inonu University Journal of the Faculty of Education, 17(3), 41-52.

Dursun, F., \& Bulut, A. (2019). Student and teacher opinions on determining the effect of active learning model on critical thinking trends. Gumushane University Journal of Social Sciences Institute, 10(3), 610-626.

Easwaramoorthy, M., \& Zarinpoush, F. (2006). Interviewing for research. Canada Volunteerism Initiative, 1-2.

Ekiz, D. (2013). Bilimsel Arastirma Yontemleri. [Scientific research methods]. (3 ${ }^{\text {rd }}$ edition). Ankara: Ani Yayincilik. 
Emery, H. (2012). A global study of primary English teachers' qualifications, training and career development. ELT Research Papers, 12(08).

Fazey, D. M., \& Fazey, J. A. (2001). The potential for autonomy in learning: Perceptions of competence, motivation and locus of control in first-year undergraduate students. Studies in Higher Education, 26(3), 345-361.

Gandara, P. \& Lucrecia, S. (2016). The teachers our English language learners need. Educational Leadership, 73(5), 32-37.

Garcia-Nevarez, A. G., Stafford, M. E., \&Arias, B. (2005).Arizona elementary teachers' attitudes toward English language learners and the use of Spanish in classroom instruction. Bilingual Research Journal, 29(2), 295-317.

Gencer, K. \& Cetin, M. (2016). The effect of family on first graders' academic success of learning mother tongue. Turkish Studies, 11(9), 441-460.

Gok-Catal, O., Sahin, H., \&Celik, F. (2018).An examination of problems encountered in the process of learning English in 6th, 7th and 8th grades. Mehmet AkifErsoy University Journal of Faculty of Education, 47, 123-136.

Guven, H., \& Akar-Vural, R. (2017). Self-evaluation of English teachers working at primary school regarding the use of smartboard. Adnan Menderes University Journal of Institute of Social Sciences, 4(2), 69-86.

Guven, H., \& Saracaloglu, A. S. (2020). Evaluation of ninth grade English course book according to teacher and specialist views. Journal of Qualitative Research in Education, 8(2), 489518.

Hall, G. (2011). Exploring English language teaching: Language in action. New York: Routledge.

Harmer, J. (2007). The practice of English language teaching. (4 ${ }^{\text {th }}$ Edition). Cambridge: Pearson/Longman.

Harwood, N. (Ed.). (2014). English language teaching textbooks: Content, consumption, production. New York: Palgrave Macmillan.

Haznedar B. (2010), Turkiye' deya bancidi legitimi: Reformlar, yonelim ler veogretmen lerimiz. [Foreign language education in Turkey: Reforms, trends and our teachers]. Paper presented at International Conference on New Trends in Education and Their Implications, Antalya, Turkey.

Hennink, M., Hutter, I., \& Bailey, A. (2020). Qualitative research methods. (2 ${ }^{\text {nd }}$ Edition). Los Angeles: SAGE Publications Limited.

Horwitz, E. K. (2001). Language anxiety and achievement. Annual Review of Applied Linguistics, 21, 112-126.

Horwitz, E. K., Horwitz, M. B., \& Cope, J. A. (1986). Foreign language classroom anxiety. The Modern Language Journal, 70(2), 125-132.

$\mathrm{Hu}, \mathrm{G}$. (2005). English language education in China: Policies, progress, and problems. Language policy, 4(1), 5-24.

iscan, A. (2011). Importance of Turkish as foreign language. International Journal of Eurasia Social Sciences, 2(4), 29-36.

Jackson, S. L. (2009). Research methods and statistics: A critical thinking approach.(3 $3^{\text {rd }}$ Edition). USA: Wadsworth, Cangage Learning.

Kaleli-Yilmaz, G. (2014). Durum Calismasi. [Case study]. In M. Metin (Ed.), Kuram danuy gulamayaegitim de bilimselar astir mayontemleri [Scientific research methods in education from theory to practice]. Ankara: PegemAkademi.

Karaata, C. (2010). Suggestions for the in-service training of English teachers who work at state schools. Milli Egitim, 185, 107-129.

Kaya, E. (2012). Teachers' opinions on the use of social studies classrooms in social studies education. Educational Sciences: Theory \& Practice, 12(2), 1015-1021. 
Kayabasi, O. \& Kose, E. (2019). Investigation of English language teachers and school principals' views on the foreign language based implementation in 5 th grades in secondary schools. International Journal of Current Approaches in Language, Education and Social Sciences (CALESS), 1(2), 101-120.

Kiraz, Z., \& Kurul, N. (2018). Unemployment of Teachers in Turkey and Unassigned Teachers' Act. Mersin University Journal of the Faculty of Education, 14(1), 270-302.

Kiryak, Z., \& Altun, T. (2019). Investigating teachers' views on the effect of subject-based classroom system on school improvement. Journal of Science, Mathematics, Entrepreneurship and Technology Education, 2(1), 25-35.

Kormos, J., \& Csizer, K. (2014). The interaction of motivation, self-regulatory strategies, and autonomous learning behavior in different learner groups. TESOL Quarterly, 48(2), 275299.

Krippendorff, K. (1989). Content analysis. In E. Barnouw, G. Gerbner, W. Schramm, T. L. Worth, \& L. Gross (Eds.), International encyclopedia of communication (Vol. 1, pp. 403-407). New York, NY: Oxford University Press.

KulaC-Puren, D. (2017). The use of motivational strategies in EFL classrooms: A guide for Turkish EFL teachers. Karaelmas Journal of Educational Sciences, 5, 395-408.

Kurt, E., \& Acat, M. B. (2016). Investigation of learner autonomy in high school students learning English as foreign language. Bolu Abant Izzet Baysal University Journal of Faculty of Education, 16(4), 1880-1902.

MacIntyre, P. D. (1999). Language anxiety: A review of the research for language teachers. In D. J. Young (Ed.), Affect in foreign language and second language learning: A practical guide to creating a low-anxiety classroom atmosphere. (pp. 24-45). Boston: McGraw-Hill.

MacIntyre, P. D., \& Gardner, R. C. (1994). The subtle effects of language anxiety on cognitive processing in the second language. Language Learning, 44(2), 283-305.

Martin, S. H. (2002). The classroom environment and its effects on the practice of teachers. Journal of Environmental Psychology, 22(1-2), 139-156.

Mavis, F. O., \& Bedir, G. (2014). $2^{\text {nd }}$ year students' and their teacher's perspectives on English language program applied for the first time in 2012-2013 academic year. International Journal on New Trends in Education and Their Implications, 5(4), 205-215.

Mavis, F. O., Cayci, D. \& Arslan, M. (2014).Evaluation of Turkey's teacher training system from the viewpoint of experienced teachers (past, present and future).Journal of Teacher Education and Educators, 3(1), 91-108.

McBurney, D. H. \& White, T. L. (2010). Research Methods. (8 ${ }^{\text {th }}$ Edition). USA: Wadsworth, Cangage Learning.

Mede, E. \& Isik, M. (2016).The needs of primary English teachers for an in-service teacher training program. Turkish Online Journal of Qualitative Inquiry, 7(2), 1-30.

Mehdiyev, E., Usta, G. \&Ugurlu, C. T. (2016). Motivation in English language learning. Electronic Journal of Social Sciences, 15(57), 361-371.

Melchor-Couto, S. (2016). Foreign language anxiety levels in second life oral interaction. ReCALL 29(1), 99-119.

MoNE (Turkish Ministry of National Education). (2014). National education statistics: Formal Education 2013/14. Ankara: Ministry of National Education Strategy Development Presidency.

Murray, D. E. \& Christison, M. (2011).What English language teachers need to know volume I: Understanding learning. New York: Routledge.

Nagahashi, T. L. (2007). Techniques for reducing foreign language anxiety: Results of a successful intervention study. Akita City: Akita University Press. 
Naser Oteir, I., \& Nijr Al-Otaibi, A. (2019). Foreign Language Anxiety: A Systematic Review. Arab World English Journal (AWEJ), 10(3), 309-317.

Nicolaidis, K. \& Mattheoudakis, M. (2008). Utopia vs. reality: The effectiveness of in-service training courses for EFL teachers. European Journal of Teacher Education,31(3), 279-292.

Noom-Ura, S. (2013). English-teaching problems in Thailand and Thai teachers' Professional development needs. English Language Teaching, 6(11), 139-147.

Norton, B. (2016). Identity and language learning: Back to the future. TESOL Quarterly,50(2), 475-479.

Nunan, D. (2015). Teaching English to speakers of other languages: An introduction. New York: Routledge.

Oxford, R. \& Shearin, J. (1994). Language learning motivation: Expanding the theoretical framework. The Modern Language Journal, 78(1), 12-28.

OzCelik, N. (2012). Prospective foreign language teachers' views of school experience and teaching practice courses.GEFAD/GUJGEF 32(2), 515-536.

Ozyurek, C., Pinarkaya, Y., \&Tas, E. (2016). The impact of rotating class system on the success levels and attitudes of the students in the light unit. ODU Journal of Social Science Research, 6(3), 657-664.

Paker, T. (2012). Turkiye'dene deny abancidil (Ingilizce) ogretemi yoruzvene denogrenci lerimiziletisim kurabilecek duzeyde ingilizce ogrenemiyor? [Why cannot we teach foreign language (English) in Turkey and why cannot our students learn English in communicative level]. Pamukkale University Journal of Education, 32(2), 89-94.

Patton, M. Q. (1990). Qualitative evaluation and research methods.(2nd Edition). SAGE Publications, Inc.

Richards, J. C. \& Rodgers, T. S. (2001). Approaches and methods in language teaching. (2 ${ }^{\text {nd }}$ Edition). New York: Cambridge University Press.

Saiti, A., \& Saitis, C. (2006). In-service training for teachers who work in full-day schools. Evidence from Greece. European Journal of Teacher Education, 29(4), 455-470.

Seidlhofer, B. (2005). Key concepts in ELT: English as a lingua franca. ELT Journal,58(4), 339341.

Sener, S., \& Mulcar, V. (2018). An Investigation of Teachers' Perceptions on English Textbooks: A Case Study of Teachers Teaching 10th Graders in Mugla. Western Anatolia Journal of Educational Sciences, 9(1), 15-37

Sevik, M. (2009). The teaching of modern foreign languages in primary schools and generalist class teachers. Ankara University, Journal of Faculty of Educational Sciences,42(1), 377401.

Short, D. J. (2017). How to integrate content and language learning effectively for English language learners. EURASIA Journal of Mathematics Science and Technology Education,13(7b), 4237-4260.

Taylor, L. (2006). The changing landscape of English: Implications for language assessment. ELT Journal, 60(1), 51-60.

Tosuncuoglu, i. (2018). English Language Teaching as lingua franca. Karaelmas Journal of Educational Sciences, 6, 326-331.

Ustunluoglu, E. (2009). Autonomy in language learning: Do students take responsibility for their learning?. Journal of Theory \& Practice in Education (JTPE), 5(2), 148-169.

White, M. D., \& Marsh, E. E. (2006). Content analysis: A flexible methodology. Library Trends, 55(1), 22-45.

Wlosowicz, T. M. (2017). English language attrition in teachers: Questions of language proficiency, language maintenance, and language attitudes. Theory and Practice of Second Language Acquisition, 3(1), 75-100. 
Woodrow, L. (2006). Anxiety and speaking English as a second language. RELC Journal, 37(3), 308-328.

Yaman, I. (2018). Learning English in Turkey: Challenges and opportunities. RumeliDE Journal of Language and Literature Studies, 11, 161-175.

YesilCinar, S. \& Cakir, A. (2018). Continuing professional development process: English language teachers" views on the role of teacher research. Journal of Language and Linguistic Studies, 14(2), 61-75.

Yigit, N. \& Altun, T. (2011). Effectiveness of an in-service training course: Teaching methods and techniques. Milli Egitim, 189, 118-130.

Yildirim, A. \&Simsek, H. (2008). Sosyal bilim lerdenitelar astir mayon temleri [Qualitative research methods in the social sciences]. Ankara: Se Ckin Yayincilik.

Young, D. J. (1991). Creating a low-anxiety classroom environment: What does language anxiety research suggest?. The Modern Language Journal, 75(4), 426-439.

\section{Appendix 1. Semi-structured interview form}

Purpose of the study: The purpose of this study is to discover the problems and proposed solutions in teaching English from the perspective of secondary school level teachers.

Interviewee:

Place of interview:.

Date/time:

Instruction: As a result of this research, the problems, opinions and suggestions of English teachers about the English language teaching will be determined. All information expressed by teachers during the interview process will be kept confidential. Names and personal information will not be used in any way except for the scope of the research.

- Is there anything you would like to say or ask before starting the interview?

- Do you allow me to record the conversation?

- I think the interview period will take about half an hour, can we start with your permission?

Ozge MAVIS SEVIM \& Fevzi DURSUN

\section{Interview Questions:}

1. Can you briefly explain how you conduct your classes as an English teacher?

a. Which teaching methods do you use?

b. Which materials do you use?

2. What are the most important problems you face while continuing your teaching activities as an English teacher? Can you summarize them briefly?

a. Do you think you can achieve the goals in the curriculum?

3. Do you have any problems regarding the educational environment you use in teaching English?

a. As an educational environment, do your school and classroom have the necessary physical characteristics?

b. Are the instructional technologies in your classes suitable for material use?

c. What are your problems and proposed solutions to educational environment problems?

4. What do you think about the pre-service and in-service trainings you received? 
a. Can you briefly mention pre-service training you receive? Is it helpful to your teaching profession or not?

b. Can you briefly mention in-service trainings you receive? Is it helpful to your teaching profession or not?

5. How do you ensure your professional development as an English teacher?

a. What kind of activities do you do to increase your language capability and pedagogical development?

6. As an English teacher, what are the problems and interactions you have with administrators?

a. Do you receive the necessary support from administrators?

b. What are your expectations from administrators as a foreign language teacher?

7. How do students' parents view English language teaching? Do you have problems with students' parents?

8. As an English teacher, what are the problems and interactions you have with other teachers (in your field and in other fields)?

a. As a foreign language teacher, what are your expectations from your field and other field teachers?

9. Is there anything you want to add?

\section{Biographical notes:}

Dr. Özge Maviş Sevim works as an assistant professor in the Department of Educational Sciences at Tokat Gaziosmanpasa University. Her research interests are English Language Teaching (ELT), teacher education, curriculum development and evaluation and graduate education.

Dr. Fevzi Dursun works as an associate professor in the Department of Educational Sciences at Tokat Gaziosmanpasa University. His research interests are teacher education, technology usage in education, teaching and learning and curriculum development and evaluation studies. 